〔Med. Entomol. Zool. Vol. 61 No. 1 p. 49-58 2010〕

\title{
A new species of black fly in the subgenus Simulium (Diptera: Simuliidae) from Thailand
}

\author{
Yao-Te HuAnG ${ }^{1)}$, Jumnongjit PhasuK ${ }^{2)}$, \\ Jariya Chanpaisaeng ${ }^{3)}$, and Peter H. AdleR ${ }^{1)}$ \\ 1) Department of Entomology, Soils \& Plant Sciences, Clemson University, Clemson, \\ SC 29634-0315 USA; (e-mail: cckaky@hotmail.com, padler@clemson.edu) \\ 2) Department of Parasitology, Faculty of Veterinary Medicine, Kasetsart University, \\ Bangkok 10900, Thailand \\ 3) Department of Entomology, Faculty of Agriculture, Kasetsart University, \\ Bangkok 10900, Thailand
}

(Received: 10 November 2009; Accepted: 5 December 2009)

\begin{abstract}
A new species of black fly, Simulium vanellum, is described and illustrated from the female, male, pupa, and larva collected in Thong Pha Phum District of Kanchanaburi Province, Thailand. It is morphologically most similar to Simulium indicum and Simulium nigrogilvum, and is tentatively placed in the Simulium griseifrons species group.
\end{abstract}

Key words: Aquatic insects, black flies, new species, Simulium, Thailand

Although Thailand ranks 50th in geographic area among all countries, it ranks 5 th in the number of nominal species of black flies, with 73 . Fourteen of these species, almost one-fifth the total described from Thailand, are in the Simulium griseifrons species group of the subgenus Simulium Latreille (Takaoka and Choochote, 2004a, 2004b, 2005a, 2005b, 2006; Adler and Crosskey, 2009). The diagnosis of the S. griseifrons group, however, has become increasingly problematic since molecular evidence indicated that members of the subgenus Himalayum Lewis are most closely related to some members of the S. griseifrons group while other species currently assigned to the $S$. griseifrons group evidently do not belong (Otsuka et al., 2003). Himalayum, consequently, was synonymized with Simulium s. str., and its two nominal species, S. indicum Becher and $S$. nigrogilvum Summers, were placed in the S. griseifrons group (Takaoka and Choochote, 2004a). Most of the diagnostic characters used to define the S. griseifrons group-adult radial vein haired basally, female claws simple, male gonostylus with prominent basal protuberance and ventral plate without toothed margins, pupal gill with six filaments, and larval postgenal cleft bullet shaped (Takaoka and Davies, 1996)-do not apply to all members currently placed in the group.

We describe a new species from Thailand that is most similar in all life stages to $S$. indicum, described from India (Assam), and to S. nigrogilvum, described from Thailand (Chiang Mai Province). We tentatively place this new species in the $S$. griseifrons group to reflect the current placement of its closest relatives (S. indicum and S. nigrogilvum), while recognizing that the group requires reevaluation.

All material was collected into $80 \%$ ethanol, including adults reared from pupae. Selected adults were dried with hexamethyldisilazane (Brown, 1993), and the associated pupal exuviae and cocoon were placed in a microvial with glycerin and 
pinned below each adult. The head and terminalia were removed from a subset of adults, cleared in gently boiling 85\% lactic acid, transferred directly to glycerin in a depression slide for microscopic examination, and stored with glycerin in microvials pinned beneath the adult. Illustrations were made using a drawing tube on an Olympus BH-2 compound microscope. Morphological terminology follows that of Adler et al. (2004). Comparisons of the new species were made with published descriptions of $S$. indicum and $S$. nigrogilvum (Lewis, 1973, 1974; Takaoka and Suzuki, 1984) and with larvae of $S$. nigrogilvum from Thailand, Chiang Mai Province, Doi Inthanon National Park (8 larvae: Huai Sai Luang waterfall, $18^{\circ} 31^{\prime} \mathrm{N}$ $98^{\circ} 27^{\prime} \mathrm{E}, 1,060 \mathrm{~m}, 3$ March 2002; 1 larva: Siriphum waterfall, $18^{\circ} 32^{\prime} \mathrm{N} \quad 98^{\circ} 31^{\prime} \mathrm{E}$, $1,380 \mathrm{~m}, 2$ March 2002). The holotype male and some paratypes ( 2 females, 57 larvae) of the new species are deposited in the National Museum of Natural History, Washington, DC, USA. Additional paratypes (1 female, 1 male, 1 pupa, and 2 larvae) are deposited in The Natural History Museum, London, and all additional specimens that were examined are in the Department of Entomology, Faculty of Agriculture, Kasetsart University, Bangkok.

\section{Simulium (Simulium) vanellum n. sp.}

(Figs. 1-3)

DESCRIPTION. Female. Scutum length 0.90-0.96 mm. Head. Slightly narrower than thorax. Frons brown, shiny, covered with golden hairs; frontal ratio $1.42: 1.00: 1.21$; frons to head ratio $1.00: 3.36$. Fronto-ocular area triangular, directed laterally. Clypeus brown, with grayish-white pruinosity and dark, scattered hairs. Antenna brown except scape, pedicel, and basal $1 / 2$ or less of 1 st flagellomere slightly paler. Maxillary palp brown; proportional lengths of $3 \mathrm{rd}, 4 \mathrm{th}$, and 5 th palpomeres $1.00: 1.15: 2.13$; sensory vesicle (Fig. 1A) ellipsoidal, with rugged surface, 0.37 times as long as 3rd palpomere, with mediumsized opening apically. Maxillary lacinia with
11 inner and 14 or 15 outer teeth. Mandible (Fig. 1C) with 34 inner and 6 vestigial outer teeth. Cibarium (Fig. 1B) with median, ragged, subtriangular process. Thorax. Scutum dark brown, densely covered with golden, recumbent, scalelike hairs; prescutellar area with brown, erect, long hairs. Scutellum pale brown, with row of golden and dark brown hairs. Postscutellum brown, shiny, bare. Pleural membrane bare. Katepisternum brown, shiny, bare. Legs. Foreleg (Fig. 1D): coxa and trochanter whitish yellow; femur whitish yellow on basal $1 / 2-4 / 5$, gradually darkened toward apex; tibia whitish yellow except apical $1 / 2$ brown; basitarsus and tarsus brown, with thick dorsal crest of short, dark brown hairs; basitarsus slightly dilated, 4.29 times as long as greatest width. Midleg (Fig. 1E): coxa brown; trochanter whitish yellow, slightly darker distally; femur with basal $1 / 4-1 / 3$ whitish yellow, remaining $2 / 3-3 / 4$ brown; tibia brown except basal $1 / 2$ pale yellow; basitarsus and tarsus brown except basal $1 / 6-1 / 2$ of basitarsus and extreme base of 1st tarsomere whitish yellow. Hindleg (Fig. 1F): coxa brown; trochanter whitish yellow; femur brown except basal 1/3-2/5 whitish yellow; tibia brown except basal $1 / 2$ whitish yellow; basitarsus and tarsus brown except basal $1 / 2$ of both whitish yellow; basitarsus (Fig. 1F) nearly parallel-sided, 5.29 times as long as wide, 0.64 and 0.52 times as wide as greatest widths of tibia and femur, respectively; calcipala (Fig. 1G) slightly shorter than its basal width, 0.31 times as wide as greatest width of basitarsus. Pedisulcus (Fig. $1 \mathrm{G})$ distinct. Claws (Fig. 1H) each with small subbasal tooth. Wing. Length $2.4-2.5 \mathrm{~mm}$; costa with spinules and hairs; subcosta with hairs ventrally; hair tuft on stem vein brownish black; base of radius fully haired; $R_{1}$ with dark brown spinules and hairs; $\mathrm{R}_{2}$ with hairs only; basal cell absent. Halter whitish, with stem beige. Abdomen. Dorsum brown except segments I-III pale gray, moderately covered with golden hairs interspersed with brown hairs. Genitalia. Sternite VIII (Fig. 1K) well sclerotized, bare medially but with 5-7 long hairs and 7 or 8 short setae on each side. Ovipositor valves (Fig. 1K) weakly sclerotized, produced posteriorly, forming transparent tonguelike processes; inner margins sinuous. Genital fork (Fig. 1K) well sclerotized, tip of stem dilated; arms each with broadly rounded process anteriorly. Anal lobe (paraproct) in ventral 


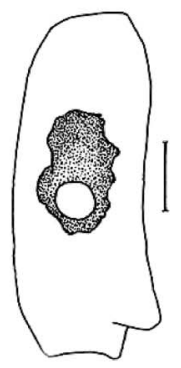

A

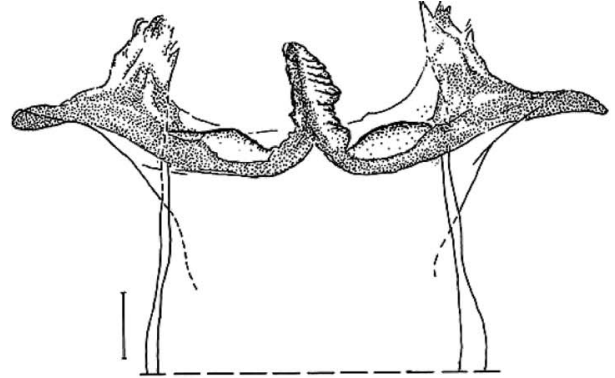

B

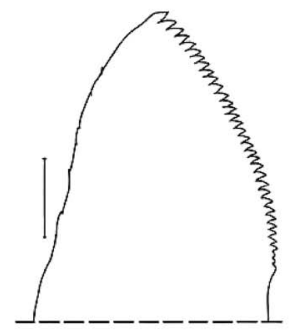

C

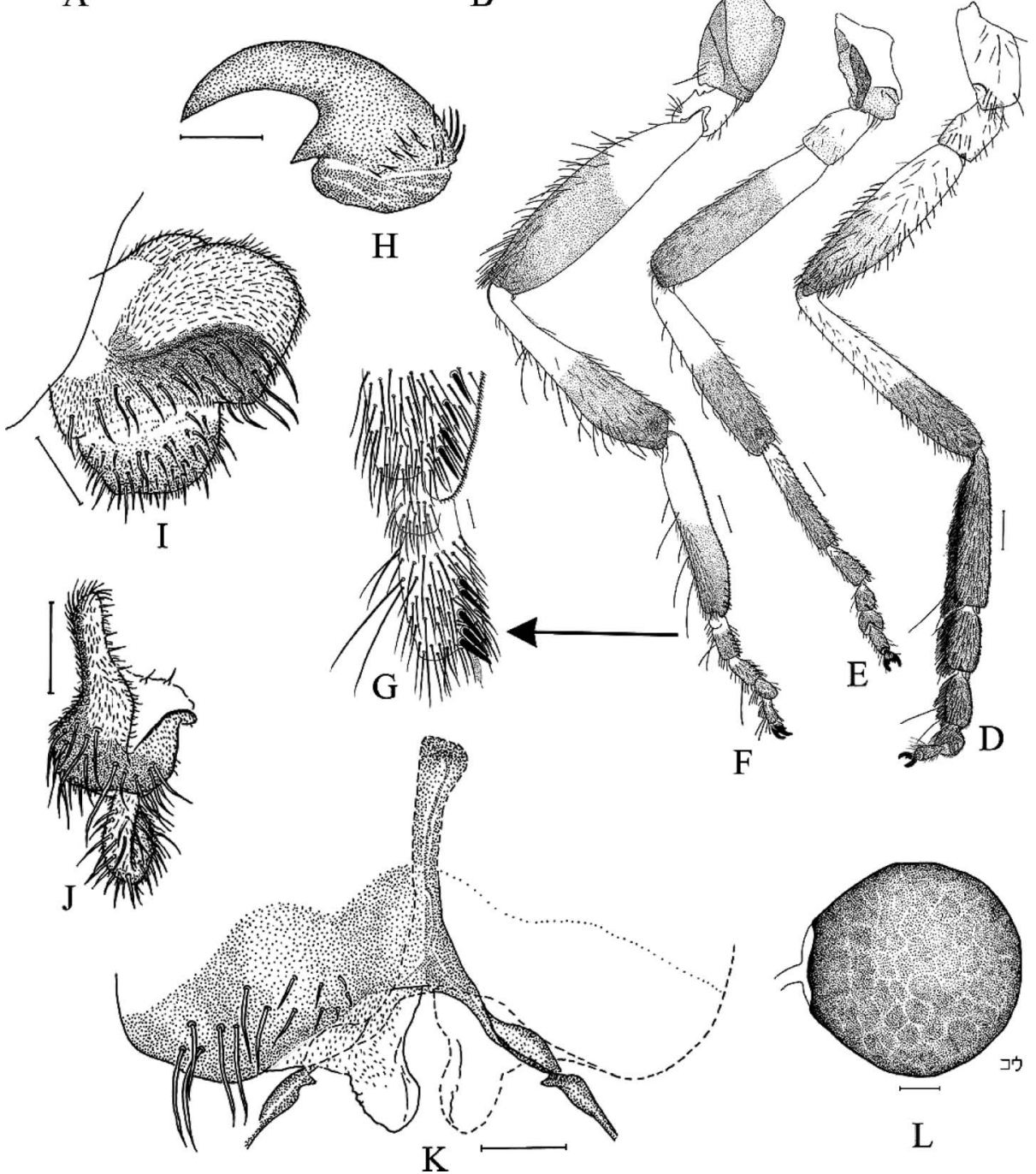

Fig. 1. Female of S. vanellum n. sp. A, 3rd segment of maxillary palp with sensory vesicle (right side and front). B, cibarium. C, mandible (apex only). D-F, foreleg, midleg, and hindleg, respectively (left side). G, basitarsus (apex only) and 2nd tarsal segment of hindleg showing calcipala and pedisulcus (left inner side). H, claw. I and J, paraprocts and cerci (right side; I, lateral; J, ventral). K, sternite 8, ovipositor valves, and genital fork (ventral); L, spermatheca. Scale bars: $0.01 \mathrm{~mm}$ for H; $0.02 \mathrm{~mm}$ for A-C, G, and L; $0.05 \mathrm{~mm}$ for I-K; $0.1 \mathrm{~mm}$ for D-F. 
view (Fig. 1J) longer than wide, lateral margins sinuous, anterior half with fewer microsetae and paler than posterior half; in lateral view (Fig. 1I) broadly rounded, ca. 1.6 times wider than long, anterior portion lightly pigmented, and posterior portion more darkly pigmented and with 18-20 long, dark hairs; in anterior view 13 or 14 short, hairlike sensilla. Cercus in lateral view (Fig. 1I) rounded posteriorly, 1.54 times as wide as long. Spermatheca (Fig. 1L) globular, well sclerotized except at junction with duct, with faint reticulate pattern on surface.

Male. Scutum length $0.78 \mathrm{~mm}$. Head. About as wide as thorax. Upper eye with 17 vertical columns and 19 horizontal rows of large facets. Clypeus brown, with whitish pruinosity and sparse, brown hairs. Antenna brown except scape, pedicel, and less than $1 / 2$ of 1 st flagellomere slightly paler; 1st flagellomere 2.09 times as long as 2nd. Maxillary palp brown; proportional lengths of 3rd, 4 th, and 5 th palpomeres $1.00: 1.22-1.24: 2.29-3.04$; 3 rd palpomere widened apically; sensory vesicle ellipsoidal, $0.23-0.24$ times as long as 3rd palpomere, with small opening apically. Thorax. Scutum dark brown, densely covered with golden, recumbent, scalelike hairs. Scutellum dark brown, with golden hairs and long, erect, brown hairs. Postscutellum brown, shiny, bare. Pleural membrane bare. Legs. Foreleg: coxa whitish yellow; trochanter light brown to brown except basal $1 / 2$ or less whitish yellow; femur pale brown, progressively darker apically with distal $1 / 4$ brown; tibia brown; basitarsus and tarsus brown with thick dorsal crest of short, dark hairs; basitarsus moderately dilated, 5.40 times as long as greatest width. Midleg: coxa brown; trochanter brown except basal $1 / 2$ whitish yellow; femur, tibia, basitarsus, and tarsus brown. Hindleg: coxa brown; trochanter whitish yellow; femur brown, darkest apically with base whitish yellow; tibia, basitarsus, and tarsus brown except basal 1/2 of 1st tarsomere pale brown; basitarsus narrow, nearly parallelsided, 4.92 times as long as greatest width, 0.65 and 0.56 times as wide as greatest widths of hind tibia and femur, respectively; calcipala slightly shorter than its basal width, 0.33 times as wide as greatest width of basitarsus; pedisulcus distinct. Wing. Length $2.4 \mathrm{~mm}$; setation nearly as in female except subcosta bare or with few hairs. Halter whitish, with stem partially brown. Abdomen. Segments I and II pale gray, segment III brown dorsally and pale gray laterally and ventrally, remaining segments brown. Segment I with basal fringe of golden hairs dorsally and longer, brown hairs laterally; all other segments with golden, recumbent hairs and segments IV-IX also with scattered brown hairs laterally; segment VI with pair of white pruinose lateral spots (bluish iridescent in light). Genitalia. Coxite in ventral view (Fig. 2A) short and subquadrate. Style in ventral view (Fig. 2A) elongate, longer than coxite, ca. 3.2 times longer than its basal width, with apical $1 / 3$ gently curved inward, tapered apically, and with a subapical spine; style in dorsal view (Fig. 2B) slightly sinuous, nearly parallel-sided; style in medial view (Fig. 2C) nearly parallel-sided from base to basal $1 / 4$, then narrowed, tapered, and gently curved toward apex. Ventral plate in ventral view (Fig. 2A) with body rather pearshaped, wider than long, rounded posterolaterally, densely covered with hairs on ventral surface except small areas along anterior and lateral margins bare, anterior portion with minute setae, posterior margin slightly concave; basal arms of ventral plate widely divergent; ventral plate with prominent median process narrowed to small rounded apex; in terminal view (Fig. 2D), body and lip forming nearly equilateral triangle; in lateral view (Fig. 2E), narrow, parallel-sided, slightly enlarged apically and projected forward. Median sclerite (Fig. 2H) slender, gradually widened toward distal $1 / 3$, then narrowed apically, apex rounded and well sclerotized anterolaterally. Paramere (Fig. 2F) broad basally, with numerous long and short hooks apically (Fig. 2G). Dorsal plate not apparent. Abdominal segment $\mathrm{X}$ bare. Cercus rounded, with 2 or 3 hairs.

Pupa. Body length $3.5-3.6 \mathrm{~mm}$. Head. Frons moderately covered with rounded tubercles; antennal sheath without protuberances; face with 1 pair of simple trichomes $(0.07 \mathrm{~mm}$ long), and frons with 1 or 2 pairs of simple trichomes (0.04 mm long). Thorax. Integument pale yellowish brown, moderately covered with rounded tubercles dorsally on anterior $2 / 3$, and relatively small tubercles elsewhere, each side with 3 simple trichomes dorsomedially (0.06-0.07 mm long), 2 simple trichomes anterolaterally (0.06-0.07 mm long), 1 simple trichome posterolaterally $(0.08 \mathrm{~mm}$ 

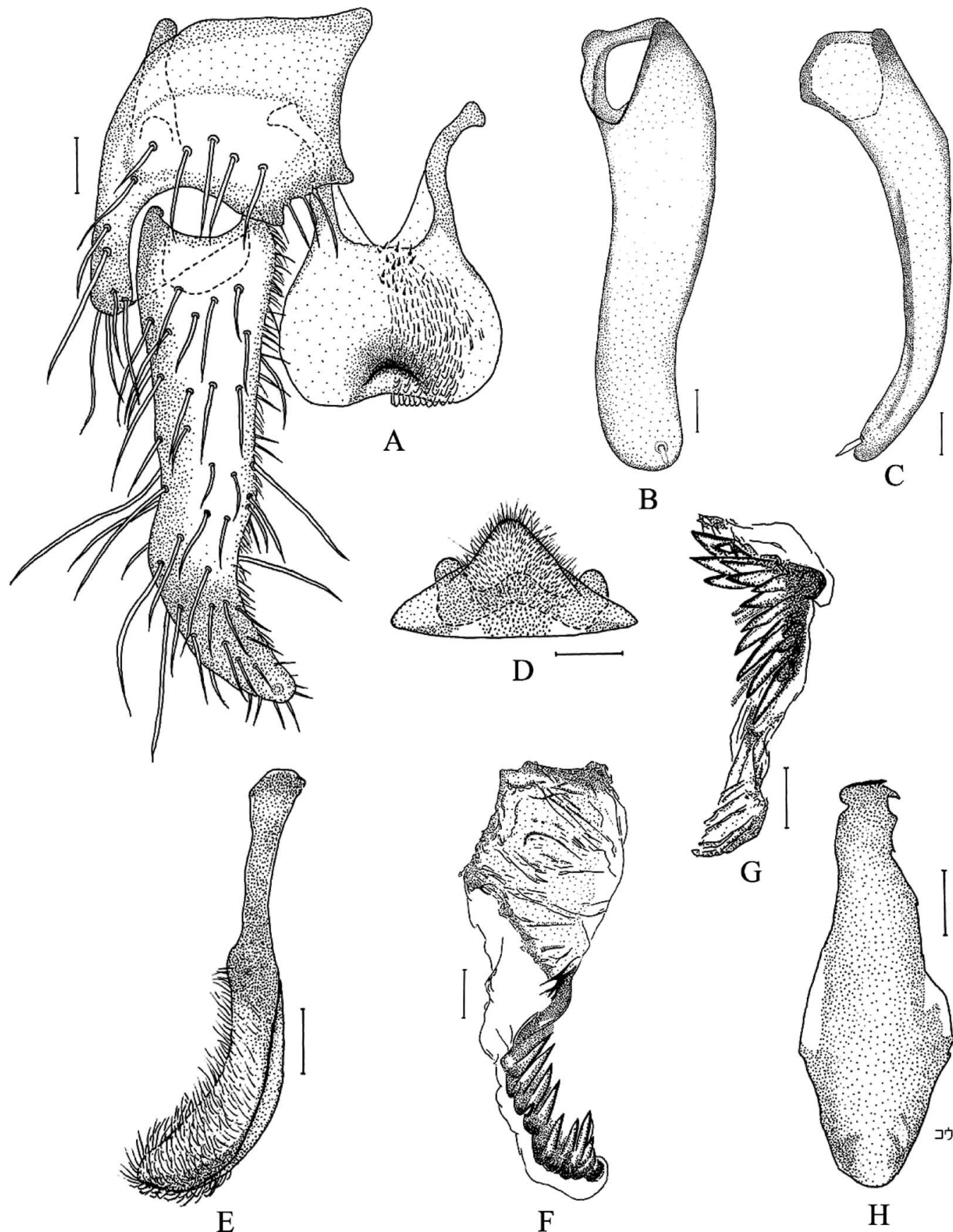

B
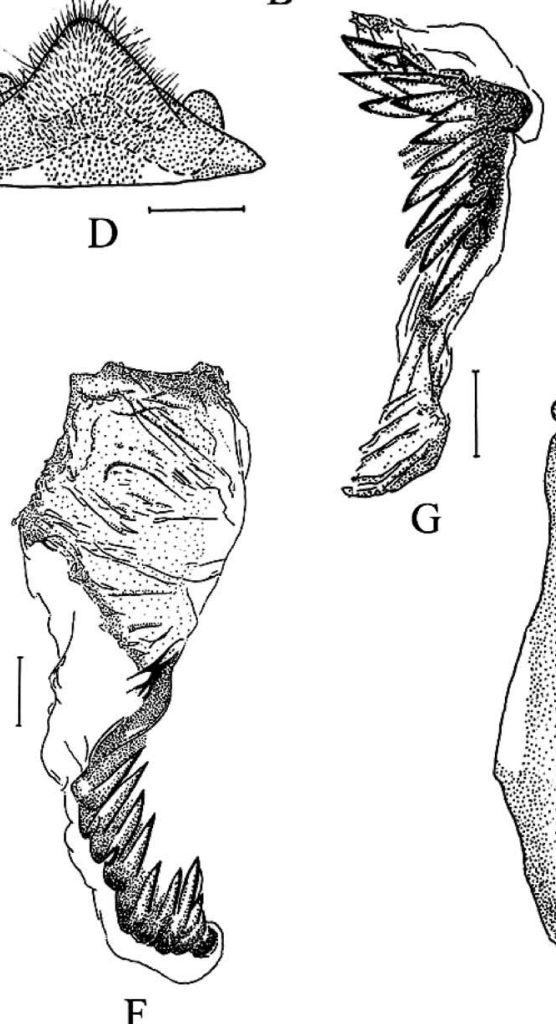

Fig. 2. Male of S. vanellum n. sp. A, gonocoxite, gonostylus, and ventral plate (ventral). B and C, gonostylus (right side; B, dorsal; C, medial). D and E, ventral plate (D, terminal; E, lateral). F, paramere (left side; lateral). G, parameral hooks (left side; dorsal). H, median sclerite (ventral). Scale bars: 0.02 $\mathrm{mm}$ for $\mathrm{A}-\mathrm{H}$. 

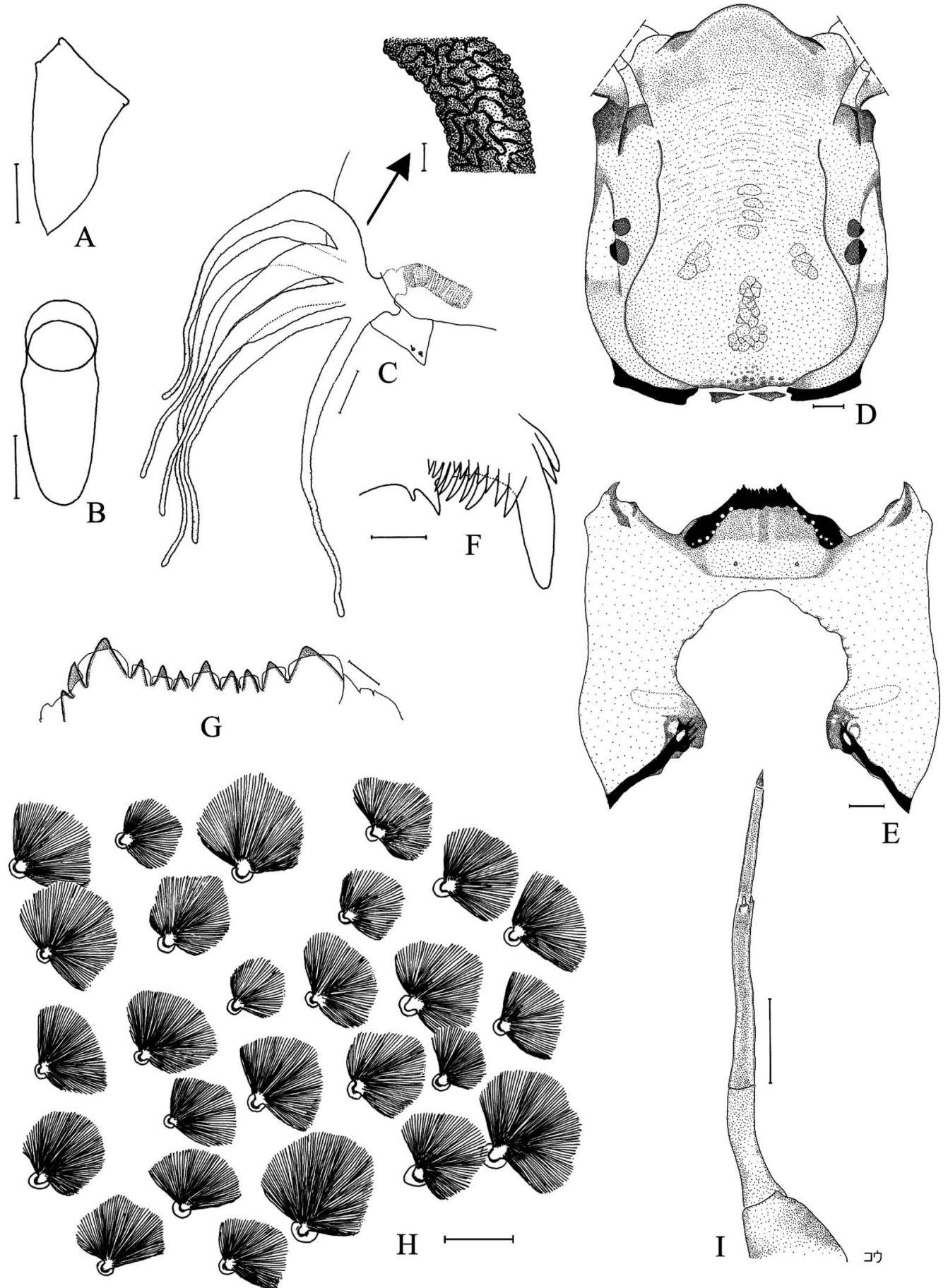

Fig. 3. Larva and pupa of S. vanellum n. sp. A and B, cocoon (A, lateral; B, dorsal). C, gill filaments, with inset showing anastomosing ridges of gill surface. D and E, larval head capsule (D, dorsal; E, ventral). F, larval mandible (apex only). G, larval hypostoma showing variation on left and right sides. H, fanlike scales on abdominal cuticle of larva. I, larval antenna (right side, dorsal). Scale bars: $0.01 \mathrm{~mm}$ for $\mathrm{G}$ and $\mathrm{H} ; 0.02 \mathrm{~mm}$ for $\mathrm{F}$; $0.05 \mathrm{~mm}$ for $\mathrm{D}$, E, and $\mathrm{I} ; 0.1 \mathrm{~mm}$ for $\mathrm{C} ; 1.0 \mathrm{~mm}$ for A and B. 
long), and 2 simple trichomes ventrolaterally (0.06 mm long). Gill (Fig. 3C) of 6 inflated filaments, about $1 / 5$ length of pupal body; filaments arranged in 3 pairs on short petioles, dorsal 2 pairs of filaments thick and tapered apically, ventral pair of filaments thinner than dorsal 2 pairs and gradually tapered apically; dorsalmost pair of filaments directed somewhat upward at base and then curved anteriorly, ventralmost filament thinnest and directed slightly ventrally; inflated portion of filaments with anastomosing pattern of ridges (Fig. 3C), apical thinner portion with transverse ridges. Abdomen. Tergite I with 2 simple, slender, short setae on each side; tergite II with 3 or 4 simple, slender, short setae and 03 simple, spinose, short setae submedially on each side; tergites III and IV each with 4 hooked spines and 1 short somewhat spinose seta on each side; tergites V-VIII with comblike groups of minute spines but without spinecombs; segment IX pale yellow, without terminal hooks. Sternite IV with few simple, slender, short setae on each side; sternite V with pair of simple hooks submedially on each side; sternites VI and VII each with pair of simple or bifid inner and simple outer hooks; sternite VI with 2 simple, slender setae on each side; sternites VII and VIII with comblike groups of minute spines. Segment IX without grapnel-shaped hooks. Cocoon (Fig. 3A, B). Length 3.2-3.4 mm long, width $1.1-1.4 \mathrm{~mm}$. Shoe-shaped, tightly woven, with anterior margin somewhat thickly woven.

Larva (mature). Body length 4.9-5.4 mm. Body pale grayish, often darkest on venter of first 4 abdominal segments; intersegmental areas without pigment. Head capsule rather uniformly brownish orange; cephalic apotome (Fig. 3D) with transverse wrinkles; head spots faintly positive, though posterolateral spots often indistinct; eyebrow faint or absent. Antenna (Fig. 3I) subequal in length to stem of labral fan; length ratio of segments (proximal to distal) $1.0: 1.35-1.46: 0.95-1.03$. Labral fan with 33-35 primary rays. Mandible (Fig. 3F) without supernumerary serrations; large tooth at acute angle; combteeth decreasing in length from 1st to 3rd. Hypostoma (Fig. 3E, G) with 9 teeth (1 larva with extra teeth on 1 side) of which median and each lateral tooth longer than others; lateral serrations weakly to moderately developed; 7 or 8 hypostomal bristles on each side. Postgenal cleft (Fig. 3E) deep, rounded, widest at midpoint, 11.0-12.7 times as long as postgenal bridge, sometimes reaching hypostoma. Subesophageal ganglion unpigmented. Pharate pupal gill with 6 inflated filaments. Thorax, abdominal segment I, and anterior $1 / 2$ of abdominal segment II with transparent, fanlike scales; remainder of abdomen with dark fanlike scales (Fig. 3H). Rectal papilla of 3 lobes, each with 10-13 fingerlike secondary lobules. Anal sclerite X-shaped, with broadened anterior arms 0.43 times as long as posterior arms; accessory sclerite ventrally, separated laterally from anal sclerite. Last abdominal segment without ventral tubercles. Posterior circlet with 119 or 120 rows of hooklets, with up to 17-19 hooklets per row.

TYPE SPECIMENS. Holotype: Male (pinned, with associated pupal exuviae and cocoon in glycerin microvial). THAILAND, Kanchanaburi Province, Thong Pha Phum District, Ban Patsaduklang, Universal Transverse Mercator (UTM) coordinates: 1608653 N 47454253 E, collected by J. Phasuk from leaf, 27 October 2002, emerged 30 October 2002. Paratypes: 3 females and 1 male (with associated pupal exuviae and cocoons), same location and collector as holotype, from leaf and plastic bag, 27 October 2002, emerged 29-30 October 2002; 57 larvae (7 mature), same location and collector as holotype, from leaf and plastic, 27 October 2002; 1 pupa (with pharate female) and 2 larvae (1 mature), same location and collector as holotype, from leaf, 26 January 2003.

ADDITIONAL SPECIMENS EXAMINED. 1 larva (mature) and 1 pupa, same location and collector as holotype, from trailing grass, 29 August 2002; 2 larvae (mature), same location and collector as holotype, from fallen tree leaf, 1 larva (mature) 14 December 2002; Ban Prajammai, Thong Pha Phum Forest, Kanchanaburi Province, UTM: 1612300 N 47454535 E, collected by J. Phasuk from fallen tree leaf, 29 August 2002. 
Table 1. Taxonomic characters of 3 closely related species of Simulium in the S. griseifrons species group.

\begin{tabular}{|c|c|c|c|c|}
\hline & & S. vanellum n. sp. & S. nigrogilvum* & S. indicum ${ }^{* *}$ \\
\hline \multirow[t]{6}{*}{ Female } & $\begin{array}{l}\text { Maxillary lacinia, inner } \\
\text { teeth }\end{array}$ & 11 & 14 & 11 \\
\hline & Mandibular teeth & 34 inner, 6 vestigial outer & $\begin{array}{l}30 \text { inner, } 5 \text { or } 6 \text { distinct } \\
\text { outer }\end{array}$ & 35 inner, 9 vestigial outer \\
\hline & Cibarium, median process & $\begin{array}{l}\text { acuminate anteriorly, } \\
\text { ragged laterally }\end{array}$ & $\begin{array}{l}\text { acuminate anteriorly, } \\
\text { ragged laterally }\end{array}$ & $\begin{array}{l}\text { rounded anteriorly, spoon } \\
\text { shaped, bearing numerous } \\
\text { minute teeth }\end{array}$ \\
\hline & Mid femur & $\begin{array}{l}\text { Basal } 1 / 4-1 / 3 \text { whitish } \\
\text { yellow, remainder brown }\end{array}$ & $\begin{array}{l}\text { Yellow, gradually } \\
\text { darkened distally }\end{array}$ & Basal $1 / 2$ pale \\
\hline & Mid tarsus & $\begin{array}{l}\text { Brown except basal } 1 / 6- \\
1 / 2 \text { of basitarsus yellow }\end{array}$ & $\begin{array}{c}\text { Brownish black except } \\
\text { basal } 1 / 3 \text { of basitarsus } \\
\text { dark yellow or brown }\end{array}$ & $\begin{array}{l}\text { Basal } 1 / 2 \text { of basitarsus } \\
\text { pale }\end{array}$ \\
\hline & Hind femur & $\begin{array}{l}\text { Brown except basal } 1 / 3- \\
2 / 5 \text { whitish yellow }\end{array}$ & $\begin{array}{l}\text { Yellow, gradually } \\
\text { darkened distally }\end{array}$ & Basal $1 / 2$ pale \\
\hline \multirow[t]{3}{*}{ Male } & $\begin{array}{l}\text { Eye, rows of dorsal facets } \\
\text { Abdomen }\end{array}$ & $\begin{array}{l}17 \text { vertical, } 19 \text { horizontal } \\
\text { Segment VI with pair of } \\
\text { white pruinose spots } \\
\text { laterally }\end{array}$ & $\begin{array}{l}20 \text { vertical, } 20 \text { horizontal } \\
\text { Segments II, VI, and VII } \\
\text { each with pair of pruinose } \\
\text { spots dorsolaterally }\end{array}$ & $\bar{r}$ \\
\hline & Ventral plate, lateral view & $\begin{array}{l}\text { Moderately protruded } \\
\text { ventrally }\end{array}$ & $\begin{array}{l}\text { Greatly protruded } \\
\text { ventrally }\end{array}$ & $\begin{array}{l}\text { Slightly protruded } \\
\text { ventrally }\end{array}$ \\
\hline & Ventral plate, ventral view & $\begin{array}{l}\text { Subquadrate, convex } \\
\text { laterally }\end{array}$ & $\begin{array}{l}\text { Subquadrate, straight } \\
\text { laterally }\end{array}$ & $\begin{array}{l}\text { Subrectangular, convex } \\
\text { laterally }\end{array}$ \\
\hline \multirow[t]{4}{*}{ Pupa } & Gill length & $1 / 5$ of pupal body & $1 / 3$ of pupal body & $2 / 5$ of pupal body \\
\hline & Gill filaments, thickness & Ventral pair thinnest & All subequal in thickness & All subequal in thickness \\
\hline & $\begin{array}{l}\text { Gill filaments, surface } \\
\text { pattern }\end{array}$ & $\begin{array}{l}\text { Inflated, basal portion } \\
\text { with anastomosing } \\
\text { ridges, thinner apical } \\
\text { portion with transverse } \\
\text { ridges }\end{array}$ & $\begin{array}{l}\text { With transverse ridges } \\
\text { and densely covered } \\
\text { with minute tubercles }\end{array}$ & - \\
\hline & $\begin{array}{l}\text { Thoracic integument, } \\
\text { dorsum }\end{array}$ & $\begin{array}{l}\text { Moderately covered with } \\
\text { rounded tubercles on } \\
\text { anterior } 2 / 3 \text { and smaller } \\
\text { tubercles elsewhere }\end{array}$ & $\begin{array}{l}\text { Moderately covered with } \\
\text { tubercles }\end{array}$ & $\begin{array}{l}\text { Smooth except few } \\
\text { anteromedian and some } \\
\text { posterior tubercles }\end{array}$ \\
\hline \multirow[t]{5}{*}{ Larva } & Body color & $\begin{array}{l}\text { Pale grayish, often darkest } \\
\text { on venter of first } 4 \\
\text { abdominal segments }\end{array}$ & Dark brown & - \\
\hline & Head capsule & Pale brownish orange & Brown & - \\
\hline & Labral fan, primary rays & $33-35$ & 42 & 29 \\
\hline & Mandible & $\begin{array}{l}\text { Without supernumerary } \\
\text { serrations }\end{array}$ & $\begin{array}{l}\text { With supernumerary } \\
\text { serrations }\end{array}$ & $\begin{array}{l}\text { With supernumerary } \\
\text { serrations }\end{array}$ \\
\hline & Posterior circlet, hooklets & $\begin{array}{l}119 \text { or } 120 \text { rows, with } \\
17-19 / \text { row }\end{array}$ & $\begin{array}{c}106 \text { (120) rows, with } \\
12-19(7-19) / \text { row }\end{array}$ & - \\
\hline
\end{tabular}

* Based on Takaoka and Suzuki (1984) and examination of larvae from Doi Inthanon National Park, Thailand (parenthetical values).

** Based on Lewis $(1973,1974)$. 
ECOLOGICAL NOTES. The larvae and pupae of Simulium (S.) vanellum n. sp. were collected in August, October, December, and January from fallen tree leaves, trailing grasses, and plastic bags in streams 2$10 \mathrm{~m}$ wide and $0.02-0.45 \mathrm{~m}$ deep exposed to the sun or partially shaded. Water temperature, $\mathrm{pH}$, and velocity at the collection sites were $20-25^{\circ} \mathrm{C}, 7.39-7.91$, and $0.3-0.8$ $\mathrm{m} / \mathrm{sec}$, respectively.

ETYMOLOGY. The specific name vanellum is from Latin and refers to the small, fanlike scales on the larval cuticle.

REMARKS. Simulium (S.) vanellum n. sp. is tentatively assigned to the $S$. griseifrons species group in the subgenus Simulium to accompany its two most morphologically similar nominal species, $S$. indicum and $S$. nigrogilvum (Table 1 ). These three species have the same shape of ovipositor valves in the female (Fig. $1 \mathrm{~K})$, a ventral plate with untoothed margins in the male (Fig. 2A), a pupal gill with six filaments (Fig. 3C), and the larval cuticle densely covered with pale and dark fanlike scales (Fig. $3 \mathrm{H}$ ). The female of $S$. vanellum n. sp. can be distinguished from that of $S$. indicum by the ragged, pointed median process of the cibarium (rounded, with spiculate surface in S. indicum), and weakly, if at all, from that of $S$. nigrogilvum by the spermatheca with a faint reticulate pattern on its surface (without a pattern in S. nigrogilvum). The type of $S$. indicum is a female from Assam, India, whereas the male, pupa, and larva that Lewis (1973) assigned to S. indicum are from Chilas, Pakistan, about $2000 \mathrm{~km}$ from the type locality of $S$. indicum. Whether these life stages are conspecific with the female type of S. indicum or are those of an undescribed species is unknown. Lewis (1973) also synonymized $S$. kashmiricum Edwards, known only from the female type, with $S$. indicum, but it, too, might represent a separate species. Careful association of the life stages of $S$. nigrogilvum from the type locality in Thai- land demonstrated its specific distinctness from S. indicum and permitted its recovery from a long history of synonymy with S. indicum (Takaoka and Suzuki, 1984). The male of S. vanellum n. sp. differs from that of putative $S$. indicum by the narrower ventral plate (ventral view), and from that of $S$. nigrogilvum by the rounded, rather than quadrate, ventral plate illustrated by Takaoka and Suzuki (1984). The pupa of S. vanellum is distinguished from that of putative $S$. indicum by the more swollen gill filaments and from that of S. nigrogilvum by the thinner pair of ventral filaments, relative to the two dorsal pairs (subequal in thickness in S. nigrogilvum). The larvae of the three species are dubitably distinguishable from one another by slight differences, such as presence or absence of supernumerary serrations on the mandible.

\section{ACKNOWLEDGMENTS}

We thank K. Damrak for field assistance, Prof. Hiroyuki Takaoka for valuable comments on the manuscript, and the Biodiversity Research and Training Program (BRT) for financial support for JP and JC. We also thank the National Research Council of Thailand (NRCT) and the Department of National Park, Wildlife and Plant Conservation. This is Technical Contribution No. 5750 of the Clemson University Experiment Station, and is based on work supported in part by NIFA/ USDA, under project number SC-1700276.

\section{REFERENCES}

Adler, P. H. and Crosskey, R. W. 2009. World blackflies (Diptera: Simuliidae): a comprehensive revision of the taxonomic and geographical inventory [2009]. 109 pp. http: / / entweb. clemson. edu / biomia/pdfs/blackflyinventory.pdf

Adler, P. H., Currie, D. C. and Wood, D. M. 2004. The Black Flies (Simuliidae) of North America. Cornell University Press, Ithaca, NY. xv+941 pp. +24 color plates.

Brown, B. V. 1993. A further chemical alternative to 
critical-point-drying for preparing small (or large) flies. Fly Times, 11: 10.

Lewis, D. J. 1973. The Simuliidae (Diptera) of Pakistan. Bull. Entomol. Res., 62: 453-470.

Lewis, D. J. 1974. Man-biting Simuliidae (Diptera) of northern India. Israel J. Entomol., 9: 23-53.

Otsuka, Y., Takaoka, H., Aoki, C. and Choochote, W. 2003. Phylogenetic analysis of the subgenus Himalayum within the genus Simulium s. 1. (Diptera: Simuliidae) using mitochondrial 16S rRNA gene sequences. Med. Entomol. Zool., 54: 113120.

Takaoka, H. and Choochote, W. 2004a. A list of and keys to black flies (Diptera: Simuliidae) in Thailand. Trop. Med. Hlth., 32: 189-197.

Takaoka, H. and Choochote, W. 2004b. Taxonomic notes on the griseifrons species-group of Simulium (Simulium) (Diptera: Simuliidae) in northern Thailand. Trop. Med. Hlth., 32: 311-327.
Takaoka, H. and Choochote, W. 2005a. A new species of Simulium (Simulium) from northern Thailand (Diptera: Simuliidae). Trop. Med. Hlth., 33: 95-101.

Takaoka, H. and Choochote, W. 2005b. Two new species of the griseifrons species-group of Simulium (Simulium) (Diptera: Simuliidae) in northern Thailand. Med. Entomol. Zool., 56: 219-235.

Takaoka, H. and Choochote, W. 2006. A new species of the griseifrons species-group of Simulium (Simulium) (Diptera: Simuliidae) in northern Thailand. Med. Entomol. Zool., 57: 115-124.

Takaoka, H. and Davies, D. M. 1996. The black flies (Diptera: Simuliidae) of Java, Indonesia. Bishop Mus. Bull. Entomol. 6, Bishop Museum Press, Hawaii. viii +81 pp.

Takaoka, H. and Suzuki, H. 1984. The blackflies (Diptera: Simuliidae) from Thailand. Jpn. J. Sanit. Zool., 35: 7-45. 